\title{
Clinical impact of pentraxin family expression on prognosis of pancreatic carcinoma
}

\author{
S Kondo*,1, H Ueno ${ }^{1}$, H Hosoi ${ }^{1}$, J Hashimoto ${ }^{2}$, C Morizane $^{1}$, F Koizumi $^{2}$, K Tamura ${ }^{3}$ and T Okusaka ${ }^{1}$ \\ ${ }^{1}$ Division of Hepatobiliary and Pancreatic Oncology, National Cancer Center Hospital, 5-1-1 Tsukiji Chuo-ku, Tokyo 104-0045, \\ Japan; ${ }^{2}$ Shien-Lab, National Cancer Center Hospital, 5-1-1 Tsukiji Chuo-ku, Tokyo 104-0045, Japan and ${ }^{3}$ Division of Breast and \\ Medical Oncology, National Cancer Center Hospital, 5-1-1 Tsukiji Chuo-ku, Tokyo 104-0045, Japan
}

Background: Inflammatory mediators may have decisive roles at different stages of tumour development. Mediators within the pentraxin family may be used as strong biomarkers in prognosis of advanced pancreatic carcinoma patients.

Methods: Using pancreatic carcinoma cell lines and gene transfectant, we measured long pentraxin (PTX3) level in culture solution and carried out cellular migration assay in vitro. In vivo study of the treatment-naive patients with advanced pancreatic carcinoma assigned to undergo gemcitabine therapy was prospectively conducted to measure and investigate the role of plasma PTX3, C-reactive protein (CRP), and eight inflammatory mediators by using collected clinical data.

Results: Elevated PTX3 production was observed in several cell lines, and a direct relationship between migratory activity and PTX3 level was identified in vitro. High PTX3 level (117 days) was significantly less than that of patients with low PTX3 level (357 days, $P<0.001$ ). Multivariate analysis of the pancreatic carcinoma revealed a strong correlation between pentraxin family member expression and prognosis of pancreatic carcinoma. The relationship between PTX3 expression and the expression of other pro-inflammatory mediators indicated that PTX3 level is positively correlated with levels of CRP, interleukin-6, and macrophageinhibitory factor.

Conclusion: Pentraxin family members, especially PTX3, may be used as promising biomarkers in the prognosis of pancreatic carcinoma patients.

Pancreatic carcinoma is one of the most lethal cancers and is the fourth leading cause of cancer-related death in developed nations (Jemal et al, 2011). As pancreatic carcinoma has a high propensity for both local invasion and distant metastasis, surgical treatment is precluded for most patients who present with an advanced stage of the disease. Despite many treatment advances that have improved the outcomes of some pancreatic carcinoma patients, standard therapy has been found to have only a modest beneficial impact on advanced-stage patients (Vincent et al, 2011), as reflected in their 5 -year overall survival (OS) of $<5 \%$ (Jemal et al, 2011).

Identification of biomarkers that accurately predict disease recurrence, response to chemotherapy, and/or prognosis would be of substantial aid in individual risk assessment and treatment selection. Identification of targets for molecular intervention in specific subsets of patients may even lead to the development of novel therapies. There is thus a need to identify a superior marker of prognosis to enable the improved survival of advanced pancreatic carcinoma patients.

Inflammatory responses have decisive roles at different stages of tumour development, including initiation, promotion, malignant conversion, invasion, and metastasis, and affect immune surveillance and response to therapy. The invasive capacity of malignant cells has been observed to increase in the presence of inflammatory cytokines, including TNF-alpha, interleukin (IL)-1beta, and IL-6, as well as transcription factors, including $\mathrm{AP}-1, \mathrm{NF}-\kappa \mathrm{B}$, and STAT3 (Mantovani et al, 2008). In a previous study, we identified C-reactive protein (CRP), which is produced via IL-6 and TNF-alpha stimulation in the liver, as an important factor in the prognosis of pancreatic carcinoma (Morizane et al, 2011). In other studies, long pentraxin (PTX3), a member of the pentraxin family, which includes CRP and whose members may have a significant role in tumour inflammatory and malignant behaviours, was 
reported to be overexpressed in several malignancies, including liposarcomas (Germano et al, 2010) and lung cancer (Diamandis et al, 2011). These findings indicate that reduction of the key inflammatory mediators may be an important means of promoting antitumour activity.

In a previous study, we had observed direct secretion of PTX3 from pancreatic carcinoma cell lines in vitro. Building on this finding, we aimed to determine the biological significance of PTX3 in pancreatic cancer via further in vitro study of several pancreatic carcinoma cells lines, as well as prospective clinical investigation of the clinical significance of plasma PTX3 expression in chemotherapynaive pancreatic carcinoma patients. We found that PTX3 expression might be a promising biomarker for pancreatic carcinoma prognosis.

\section{MATERIALS AND METHODS}

Cells, plasmids, and transfection procedures. The PANC-1 (ATCC number: CRL-1469), MIA PaCa-2 (ATCC number: CRL-1420), BxPC-3 (ATCC number: CRL-1687), and AsPC-1 (ATCC number: CRL-1682) pancreatic carcinoma cell lines were obtained from the American Type Culture Collection (Rockville, MD, USA). Dulbecco's Modified Eagle's Medium with $10 \%$ fetal bovine serum (FBS) was used as the base medium for the PANC-1 and MIA PaCa-2 lines, and RPMI with $10 \%$ FBS was used as the growth medium for the BxPC-3 and AsPC-1 lines. We used the transfectant pCMV6-entry PTX3 open reading frame (ORF) clones (OriGene Technologies, Inc., Rockville, MD, USA; cat. no. RC207922) to investigate the cellular activity induced by intracellular PTX3 overexpression. The plasmids were transfected into cells using Lipofectamine 2000 (Life Technologies Corp., Carlsbad, CA, USA). In experiments using neomycin-resistant vectors, transfected cells were selected using $0.5 \mathrm{mg} \mathrm{ml}^{-1}$ of G-418 to establish stable transformants.

Cell migration and invasion assay. Cell migration assay was performed as described previously using Transwell inserts (5- $\mu \mathrm{M}$ pore size; Corning Inc., Corning, NY, USA). Cells were placed in $100 \mu \mathrm{l}$ of $0.6 \%$ FBS medium in the upper chamber at $1 \times 10^{5}$ cells $\mathrm{ml}^{-1}$, and the bottom chamber contained VEGF (Cat. no. PHC9391; Life Technologies Corp.), PTX3 (Cat. no. 1826-TS-025; R\&D System, Minneapolis, MN, USA), and CRP (Cat. no. 1707-CR-200; R\&D System) in a medium containing 0.6 or $20 \%$ FCS. After $12 \mathrm{~h}$, the inserts were fixed and stained with Diff-Quick (Symex International Reagents Co. Ltd., Kobe, Japan). After the cells that had not migrated were removed from the upper surface of the inserts using cotton swabs, images from three different high-power fields were captured from each insert and the number of migratory cells was counted (Kondo et al, 2012a).

Cytokine measurement. Pancreatic carcinoma cells at $75-80 \%$ confluence were growth-arrested by FBS deprivation for $24 \mathrm{~h}$ and cultured in fresh FBS-free medium. Supernatants were collected at $6 \mathrm{~h}$. Plasma samples collected from patients before initiation of gemcitabine treatment were stored at $-80^{\circ} \mathrm{C}$ until being subjected to enzyme-linked immunosorbent assay (ELISA) and antibodysuspension bead array analysis. Serum CRP levels were measured according to the manufacturer's directions by using a commercially available kit (Nanopia CRP; Sekisui Medical Co., Ltd., Tokyo, Japan) capable of assaying a wide range of values $\left(0.01-100 \mathrm{mg} \mathrm{dl}^{-1}\right)$ without the prozone phenomenon. Plasma-PTX3 levels were measured according to the manufacturer's directions by using a commercially available ELISA kit (Cat. no. PP-PD03-E0; Perseus Proteomics, Inc, Tokyo, Japan) capable of measuring a wide range of values $\left(0.1-20 \mathrm{ng} \mathrm{ml}^{-1}\right)$ linearly. After being drawn into prechilled tubes containing ethylenediaminetetraacetic acid (EDTA), peripheral blood was immediately subjected to centrifugation at $1000 \mathrm{~g}$ and $4{ }^{\circ} \mathrm{C}$ for $15 \mathrm{~min}$. The plasma was then transferred into microtubes and subjected to further centrifugation at $10000 \mathrm{~g}$ and $4{ }^{\circ} \mathrm{C}$ for $10 \mathrm{~min}$ to remove contaminating platelets.

The plasma concentrations of the pro-inflammatory mediators IL-1beta, IL-6, C-C motif ligand (CCL) 2, CCL3, CCL4, CCL7, C-X-C motif ligand 9, and macrophage-inhibitory factor (MIF) were assayed in a subgroup of patients and control individuals using the Bio-Plex suspension array system (Bio-Rad, Hercules, CA, USA), which allows for simultaneous detection of cytokines in a 96-well filter plate. In brief, the appropriate cytokine standards and diluted plasma samples were added to a 96-well filter plate and incubated at room temperature for $30 \mathrm{~min}$ with antibodies chemically attached to fluorescent-labelled micro beads. After three filter washes, premixed detection antibodies were added to each well and incubated for $30 \mathrm{~min}$. After three additional washes, premixed streptavidin-phycoerythrin was added to each well for $10 \mathrm{~min}$ of incubation. Subsequent to three more washes, the beads were resuspended in $125 \mu \mathrm{l}$ of assay buffer and the reaction mixture was quantified by using the Bio-Plex protein array reader. Data were automatically collected and analysed using Bio-Plex Manager Software 4.1, and the standard curve was obtained using a recombinant cytokine standard (Kondo et al, 2012b).

Study approval. Prior to initiation, this prospective study had been approved by the Institutional Review Board of the National Cancer Center, and written informed consent had been obtained from all patients. This study is registered with the University Hospital Medical Information Network in Japan (UMIN; number UMIN000002323) and has been completed.

Patient selection and blood sample collection. A total of 78 chemotherapy-naive patients with histologically or cytologically confirmed advanced or recurrent invasive ductal pancreatic carcinoma were prospectively enroled in this study between April 2009 and March 2010 for treatment with gemcitabine chemotherapy. Patients with coexisting infections and/or cardiovascular illness were excluded from participation. Prior to initiation of gemcitabine treatment, each patient had undergone collection of a detailed history; physical examination; assessment of pretreatment baseline laboratory parameters; and determination of baseline tumour status by computed tomography (CT) of the chest, abdomen, and pelvis. Baseline and post-treatment laboratory parameters were evaluated by performing peripheral blood sampling prior to treatment initiation and on day $28 \pm 7$ after treatment initiation, respectively. Gemcitabine at a dosage of $1000 \mathrm{mg} \mathrm{m}^{-2}$ was administered intravenously for $30 \mathrm{~min}$ on days 1,8 , and 15 of a 28 -day cycle until disease progression, unacceptable toxicity, or patient refusal to continue treatment. The data collected included those pertaining to standard demographics; disease characteristics; and disease chronology, including the dates of initial treatment, best response to treatment, progression, and death or final follow-up. Tumours were evaluated every 6-8 weeks after initiation of each course of gemcitabine, and the best responses were documented according to the Response Evaluation Criteria in Solid Tumours version 1.1 (RECIST ver1.1).

Statistical analyses. The cutoff points used in the assessment of high and low expression levels of each mediator were based on the mean values of these mediators, whereas those of the CRP and CA19-9 levels were based on previous reports (Morizane et al, 2011). Associations between patient characteristics were assessed by $\chi^{2}$ statistics. Survival in terms of both progression-free survival (PFS) and OS; demographic factors, including age and gender; and clinical factors, including Eastern Cooperative Oncology Group (ECOG) performance status (PS) and clinical stage was examined using the Cox proportional hazards model. The survival curves for PFS and OS were estimated using the Kaplan-Meier method, with the resulting Kaplan-Meier curves used only to identify trends in the associations between the inflammatory mediators and PFS and 
OS, as determination of the optimal cutoff point for the mediators relative to PFS and OS was beyond the scope of this study. All statistical analyses were performed using IBM SPSS Statistics 18 software (IBM Corp, Somers, NY, USA).

\section{RESULTS}

PTX3 expression in pancreatic carcinoma cell lines. Measurement of expression of elevated levels of PTX3 by pancreatic carcinoma cells in culture solution, considered an indication of direct PTX3 secretion by these cells, revealed that the PANC-1 and
MIA PaCa-2 cell lines expressed higher levels of PTX3 compared with the AsPC-1 and BxPC-3 lines (Figure 1A).

Effect of PTX3 on migratory and invasive potential of pancreatic carcinoma cell lines. To determine the association between the intra- and extracellular levels of PTX3 and the migratory or invasive behaviour of pancreatic carcinoma cells, pCMV6-entry PTX3 ORF clones were used to establish stable transfectants. As shown in Figure 1B, introduction of PANC-1 and AsPC-1 cells increased recombinant human (rh) PTX3-induced cell migration, with the level of migration activity depending on the concentration of extracellular PTX3. On the other hand, CRP was
A

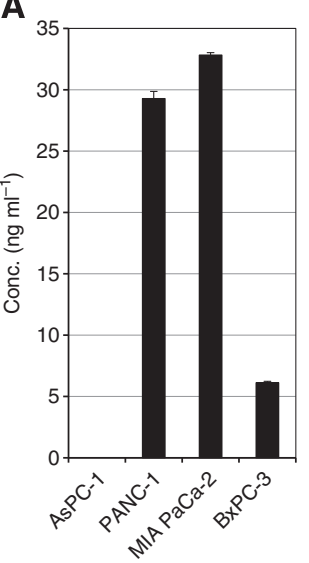

B

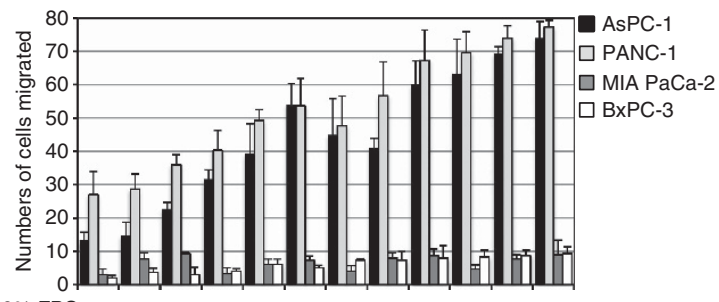

$20 \%$ FBS -

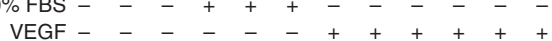

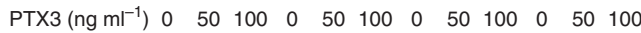

C

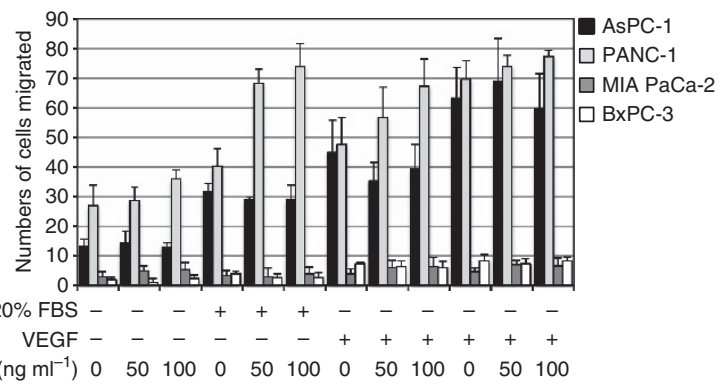

Figure 1. (A) Pentraxin 3 production levels of supernatants used for culturing of pancreatic carcinoma cell lines. (B, C) Cell migration assay in the presence or absence of the indicated reagents. NT (non-treated), FBS, 20\% in the lower chamber; VEGF, $50 \mathrm{ng} \mathrm{ml}^{-1}$ in the lower chamber; PTX3, 50-100 $\mathrm{ng} \mathrm{ml}^{-1}$; CRP, 50-100 $\mathrm{ng} \mathrm{ml}^{-1}$. Statistical significance was evaluated by comparison with or without the presence of PTX3 and CRP.

A

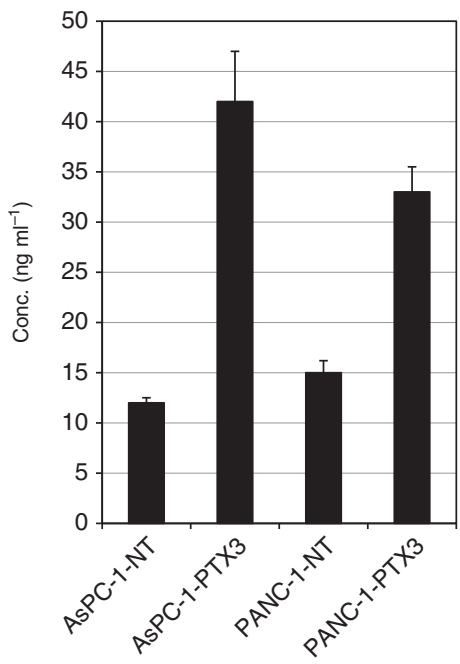

B

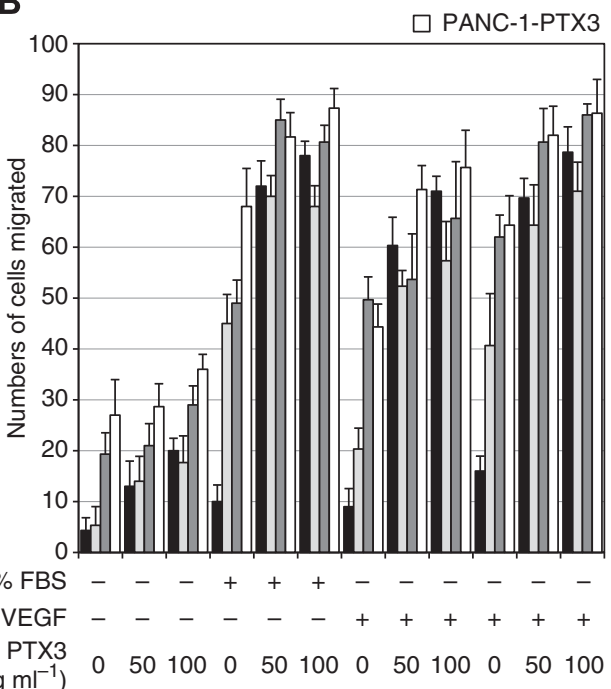

Figure 2. (A) Pentraxin 3 production levels of supernatants used for culturing of PTX3 and NT-control transfectant of pancreatic carcinoma cell lines. (B) Cell migration assay using pancreatic carcinoma cell lines (AsPC-1 and PANC-1) transfected with pCMV6-entry PTX3 ORF in the presence or absence of the indicated reagents. NT (non-treated), FBS, $20 \%$ in the lower chamber; VEGF, $50 \mathrm{ng} \mathrm{ml}^{-1}$ in the lower chamber; PTX3, 50-100 $\mathrm{ng} \mathrm{ml}^{-1}$; CRP, 50-100 $\mathrm{ng} \mathrm{ml}^{-1}$. Stable transformants were subjected to cell migration assay. 
observed to have a significant role in the regulation of migration activity in pancreatic carcinoma cell lines (Figure 2C). Transformants of PTX3 clone was not observed to increase migration activity significantly (Figure $2 \mathrm{~B}$ ). These results indicate that the extracellular PTX3 in the pancreatic carcinoma cell lines had promoted migratory activity.

Patient characteristics. Of the 78 pancreatic carcinoma patients prospectively enroled in this study, $42(54 \%)$ were male and the median age was 68 years (range, 44-79 years). Regarding prior diagnosis and treatment, 25 patients $(32 \%)$ presented with locally advanced pancreatic carcinoma, 47 (60\%) presented with metastases, and $6(8 \%)$ had been enroled following recurrence after surgery. Regarding the ECOG PS score, 44 patients (56\%) had an ECOG PS of PS0, 27 (35\%) of PS1, and 7 (9\%) of PS2. Histologically, 31 patients (40\%) had a poorly differentiated adenocarcinoma, 27 (35\%) had a moderately differentiated adenocarcinoma, 1 (1\%) had a well-differentiated adenocarcinoma, $2(2 \%)$ had an adenosquamous carcinoma, and 17 (22\%) had a cytological adenocarcinoma. Regarding response to treatment, 0 patients $(0 \%)$ experienced complete response to treatment, 5 (6\%) experienced partial response (PR) to treatment, 43 (55\%) experienced stable disease (SD) after treatment, 27 (35\%) experienced progressive disease, and $3(4 \%)$ patients were not evaluable after treatment (Table 1). The mean PTX3 level of all patients was $4.94 \pm 3.63 \mathrm{ng} \mathrm{ml}^{-1}$ (range, $0.9-17.7 \mathrm{ng} \mathrm{ml}^{-1}$; median, $3.76 \mathrm{ng} \mathrm{ml}^{-1}$ ). Regarding the values of other inflammatory mediators, the mean IL-1beta, IL-6, CCL2, CCL3, CCL4, CCL7, CXCL9, and MIF levels were found to be $95.48 \pm 37.62, \quad 294.38 \pm 516.6, \quad 746.58 \pm 518.12, \quad 177.8 \pm 58.4$, $2886.28 \pm 1974.73, \quad 80.81 \pm 13.72, \quad 3161.89 \pm 2146.07, \quad$ and $7240.52 \pm 5461.4 \mathrm{pg} \mathrm{ml}^{-1}$, respectively.

Relationship between PTX3 level and treatment outcome. For comparison of the clinical parameters associated with PTX3 level, the patients were divided into two groups: a group of patients with a PTX3 level $\geqslant 4.94 \mathrm{ng} \mathrm{ml}^{-1}$, referred to as the PTX3 ${ }^{\text {high }}$ group $(n=22)$, and a group with a PTX3 level $<4.94 \mathrm{ng} \mathrm{ml}^{-1}$, referred to as the PTX $3^{\text {low }}$ group $(n=56)$. The median PFS of the PTX $3^{\text {high }}$ group was 76 days (95\% confidence interval (CI), 43-109) and that of the PTX ${ }^{\text {low }}$ group was 150 days (95\% CI, 131-197; log-rank test, $P=0.002$; Figure $3 \mathrm{~A})$. The median OS of the PTX $3^{\text {high }}$ group was 117 days (95\% CI, 82-152) and that of the PTX $3^{\text {low }}$ group was 357 days (95\% CI, 239-475; log-rank test, $P<0.001$; Figure $3 \mathrm{~B}$ ).

Placement in the PTX $3^{\text {high }}$ group was found to be significantly associated with advanced clinical stage $(P<0.01)$, poor PS (PS2, $P=0.01$ ), and elevated CRP level (over $1.0 \mathrm{mg} \mathrm{dl}^{-1}, P<0.01$ ). The results of the univariate Cox regression analysis indicated that high PTX3 level and/or high CRP level is significantly associated with poor OS (hazard ratio (HR), 4.80; 95\% CI, 2.62-8.78; $P<0.001$ and HR, 6.56; 95\% CI, 3.32-12.96; $P<0.001$, respectively). The results of univariate analysis indicated that clinical stage (IV + recurrence vs III), PS (2 vs $0+1)$, histological differentiation (poorly differentiated $v s$ not poorly differentiated), CA19-9 level (>3000 $v s<3000 \mathrm{U} \mathrm{ml}^{-1}$ ), and IL-6 level (IL-6 ${ }^{\text {high }}$ vs IL-6 $^{\text {low }}$ ) are significantly associated with improved OS (Table 2), whereas age, gender, and levels of several pro-inflammatory mediators (IL-1beta, CCL2, CCL3, CCL4, CCL7, CXCL9, and MIF) are not. Subsequent multivariate Cox regression analysis indicated that CRP level $\left(\mathrm{CRP}^{\text {high }}\right.$ vs $\mathrm{CRP}^{\text {low }}$; HR 2.59, 95\% CI 1.05-6.36, $P=0.04$ ), and PTX3 level (PTX3 $3^{\text {high }}$ vs $\mathrm{PTX} 3^{\text {low }}$; HR $3.00,95 \%$ CI $1.47-6.14, P=0.003)$ are independent prognostic variables (Table 2). Taken together, these results suggest that members of the pentraxin family, particularly PTX3, may be predictive biomarkers in the prognosis of human pancreatic carcinoma in the clinical setting.

Relationship between PTX3 level and expression of pro-inflammatory mediators. Examination of the relationship

\begin{tabular}{|c|c|c|c|c|}
\hline & \multicolumn{2}{|c|}{$\begin{array}{c}\text { PTX3 group } \\
\text { (number of patients) }\end{array}$} & \multirow[b]{2}{*}{ Total } & \multirow[b]{2}{*}{$\begin{array}{c}\boldsymbol{P} \text { - } \\
\text { value* }\end{array}$} \\
\hline & $\begin{array}{l}\text { PTX } 3^{\text {high }} \\
\text { group }\end{array}$ & $\begin{array}{l}\text { PTX3 } 3^{\text {low }} \\
\text { group }\end{array}$ & & \\
\hline \multicolumn{5}{|l|}{ Age (years) } \\
\hline Over 70 & 7 & 21 & 28 & 0.79 \\
\hline Below 70 & 15 & 35 & 50 & \\
\hline \multicolumn{5}{|l|}{ Sex } \\
\hline Male & 15 & 27 & 42 & 0.14 \\
\hline Female & 7 & 29 & 36 & \\
\hline \multicolumn{5}{|l|}{ Stage } \\
\hline III & 1 & 24 & 25 & 0.005 \\
\hline IV & 19 & 28 & 47 & \\
\hline Recurrence & 2 & 4 & 6 & \\
\hline \multicolumn{5}{|l|}{ ECOG PS score } \\
\hline 0 & 7 & 37 & 44 & 0.01 \\
\hline 1 & 13 & 14 & 27 & \\
\hline 2 & 2 & 5 & 7 & \\
\hline \multicolumn{5}{|l|}{ Histology } \\
\hline Well differentiated & 0 & 1 & 1 & 0.12 \\
\hline Poorly differentiated & 7 & 24 & 31 & \\
\hline Moderately differentiated & 12 & 15 & 27 & \\
\hline Adenosquamous & 1 & 1 & 2 & \\
\hline NE (cytology only) & 2 & 15 & 17 & \\
\hline \multicolumn{5}{|l|}{ Tumour response } \\
\hline Partial response & 2 & 3 & 5 & 0.29 \\
\hline Stable disease & 9 & 34 & 43 & \\
\hline Progressive disease & 10 & 17 & 27 & \\
\hline $\mathrm{NE}$ & 0 & 3 & 3 & \\
\hline \multicolumn{5}{|l|}{ CA19-9 $\left(\mathrm{U} \mathrm{ml}^{-1}\right)$} \\
\hline Over 10000 & 11 & 24 & 35 & 0.62 \\
\hline Below 10000 & 11 & 32 & 43 & \\
\hline \multicolumn{5}{|l|}{ CRP $\left(\mathrm{mg} \mathrm{dl}^{-1}\right)$} \\
\hline Over 1.0 & 12 & 10 & 22 & 0.002 \\
\hline Below 1.0 & 10 & 46 & 56 & \\
\hline
\end{tabular}

between PTX3 expression and the expression of other pro-inflammatory mediators using Spearman's rank correlation coefficient analysis indicated that PTX3 level is positively correlated with level of CRP $(r=0.56, P<0.001)$, IL-6 $(r=0.59$, $P<0.001)$, and MIF $(r=0.38, P=0.001$; Table 3$)$.

\section{DISCUSSION}

The findings of the present study provide the first evidence of the clinical importance of PTX3 expression as a prognostic factor in pancreatic carcinoma due to its involvement in cancer cell behaviour. Specifically, several pancreatic carcinoma cell lines 

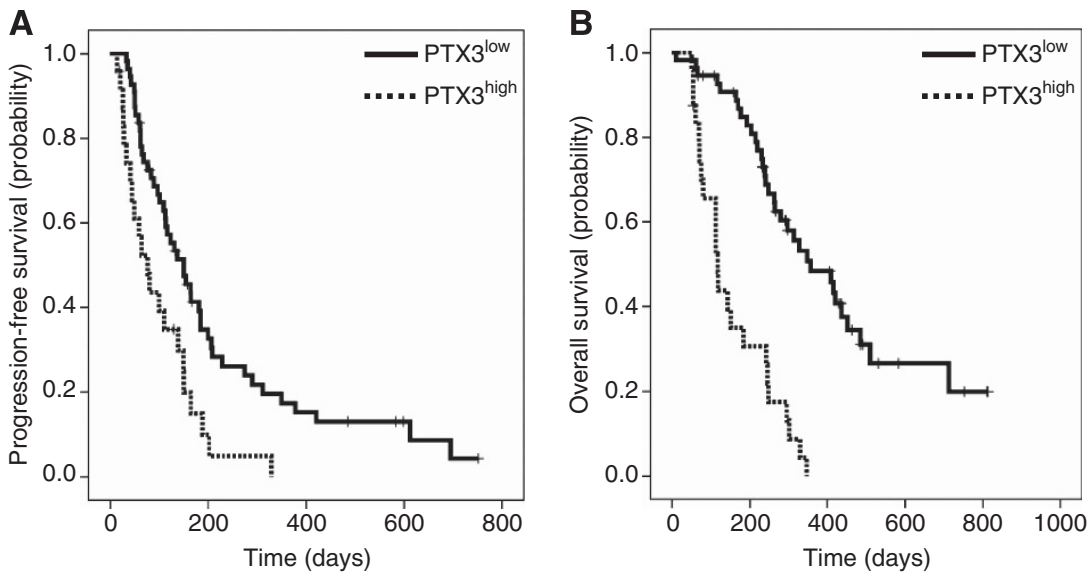

Figure 3. Kaplan-Meier curves for (A) progression-free survival according to blood-PTX3 level and (B) overall survival according to blood-PTX3 level. Cutoff points for PTX3 level were based on mean PTX3 level.

Table 2. Results of univariate and multivariate analyses

\begin{tabular}{|c|c|c|c|}
\hline & HR & $95 \% \mathrm{Cl}$ & $\boldsymbol{P}$-value ${ }^{\star}$ \\
\hline \multicolumn{4}{|l|}{ Univariate analysis } \\
\hline 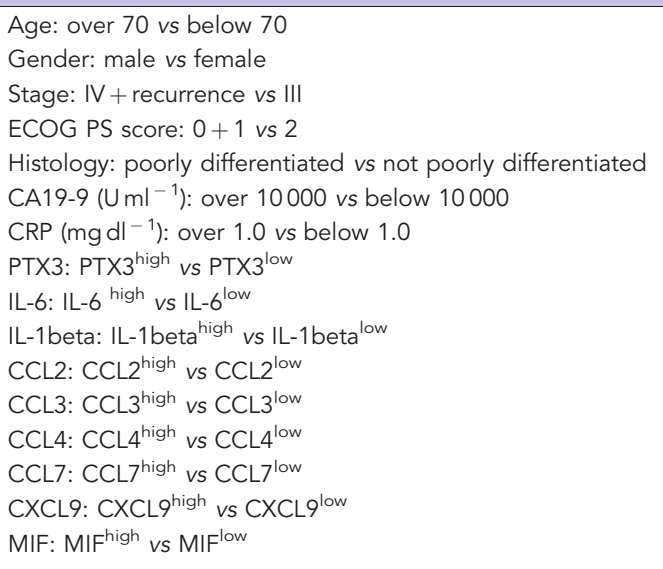 & $\begin{array}{l}1.16 \\
1.12 \\
1.93 \\
3.42 \\
2.34 \\
1.96 \\
6.56 \\
4.80 \\
7.72 \\
0.84 \\
1.40 \\
1.57 \\
1.15 \\
1.08 \\
1.51 \\
1.21\end{array}$ & $\begin{array}{l}0.66-2.05 \\
0.85-1.47 \\
1.05-3.56 \\
1.40-8.37 \\
1.34-4.12 \\
1.12-3.44 \\
3.32-12.96 \\
2.62-8.78 \\
3.88-15.35 \\
0.48-1.47 \\
0.79-2.45 \\
0.92-2.68 \\
0.64-2.06 \\
0.62-1.88 \\
0.87-2.63 \\
0.70-2.09\end{array}$ & $\begin{array}{c}0.61 \\
0.41 \\
0.03 \\
0.007 \\
0.003 \\
0.02 \\
<0.001 \\
<0.001 \\
<0.001 \\
0.84 \\
0.25 \\
0.10 \\
0.65 \\
0.79 \\
0.15 \\
0.50\end{array}$ \\
\hline \multicolumn{4}{|l|}{ Multivariate analysis } \\
\hline $\begin{array}{l}\text { Stage: IV + recurrence vs III } \\
\text { ECOG PS: } 0+1 \text { vs } 2 \\
\text { Histology: poorly differentiated vs not poorly differentiated } \\
\text { CA19-9 }\left(\mathrm{U} \mathrm{ml}^{-1}\right) \text { : over } 10000 \text { vs below } 10000 \\
\text { CRP }\left(\mathrm{mg} \mathrm{dl}^{-1} \text { ): over } 1.0 \text { vs below } 1.0\right. \\
\text { PTX3: } \text { PTX }^{\text {high }} \text { vs PTX3 } 3^{\text {low }} \\
\text { IL-6: IL-6 } \text { high vs IL-6 }^{\text {low }}\end{array}$ & $\begin{array}{l}1.14 \\
2.11 \\
1.19 \\
1.52 \\
2.59 \\
3.00 \\
2.57\end{array}$ & $\begin{array}{c}0.42-2.37 \\
0.71-6.25 \\
0.60-2.38 \\
0.84-2.74 \\
1.06-6.36 \\
1.4-6.14 \\
1.00-6.59\end{array}$ & $\begin{array}{l}0.72 \\
0.18 \\
0.62 \\
0.16 \\
0.04 \\
0.003 \\
>0.05\end{array}$ \\
\hline
\end{tabular}

were observed to secrete PTX3 to a remarkable extent, with expression of extracellular PTX3 promoting pancreatic carcinoma cell migration in a concentration-dependent, highly efficient manner and expression of transformants of PTX3 promoting migration in a less-efficient manner. Supporting this observation, evaluation of clinical blood samples of pancreatic carcinoma patients revealed a strong correlation between blood-PTX3 level and prognosis of the disease.

PTX3 is known to be produced by a variety of cells at the site of infection or inflammation, including macrophages, dendritic cells (Doni et al, 2003), neutrophils (Jaillon et al, 2007), endothelial cells
(Norata et al, 2008), epithelial cells (Han et al, 2005), fibroblasts (Doni et al, 2008), and vascular smooth muscle cells (Klouche et al, 2004). In human liposarcomas, increased levels of PTX3 RNA and intracellular PTX3 have been detected (Willeke et al, 2006), whereas elevated levels of serum PTX3 have been observed in patients with lung cancer (Diamandis et al, 2011) and prostate cancer (Sardana et al, 2008). In the present study, detection of the direct secretion of extracellular PTX3 by several pancreatic carcinoma cell lines indicated the existence of a PTX3 autocrine-paracrine loop that regulates angiogenesis and stromal cell activity. 
Table 3. Relationship between PTX3 level and levels of other immunological factors

\begin{tabular}{|c|c|c|c|c|c|c|c|c|c|c|c|}
\hline & $\begin{array}{c}\text { Average } \\
\text { (SD) }\end{array}$ & CRP & $\begin{array}{c}\text { PTX } \\
3\end{array}$ & IL-6 & IL-1beta & $\begin{array}{c}\mathrm{CCL} \\
2\end{array}$ & $\begin{array}{c}\mathrm{CCL} \\
3\end{array}$ & $\begin{array}{c}\text { CCL } \\
4\end{array}$ & $\begin{array}{c}\mathrm{CCL} \\
7\end{array}$ & $\begin{array}{c}\text { CXCL } \\
9\end{array}$ & MIF \\
\hline $\begin{array}{c}\text { CRP } \\
\left(\mathrm{mg} \mathrm{dl}^{-1}\right)\end{array}$ & $\begin{array}{c}1.57 \\
(3.06)\end{array}$ & & $\begin{array}{l}{ }^{*} r=0.56 \\
P<0.001\end{array}$ & $\begin{array}{c}0.71 \\
<0.001\end{array}$ & $\begin{array}{l}0.25 \\
0.03\end{array}$ & $\begin{array}{l}0.13 \\
0.26\end{array}$ & $\begin{array}{l}0.10 \\
0.40\end{array}$ & $\begin{array}{l}0.04 \\
0.73\end{array}$ & $\begin{array}{l}0.03 \\
0.77\end{array}$ & $\begin{array}{c}0.31 \\
<0.01\end{array}$ & $\begin{array}{l}0.28 \\
0.01\end{array}$ \\
\hline $\begin{array}{c}\text { РТX3 } \\
\left(\mathrm{ng} \mathrm{ml}^{-1}\right)\end{array}$ & $\begin{array}{c}4.94 \\
(3.63)\end{array}$ & $\begin{array}{c}0.56 \\
<0.001\end{array}$ & & $\begin{array}{c}0.59 \\
<0.001\end{array}$ & $\begin{array}{l}0.19 \\
0.09\end{array}$ & $\begin{array}{l}0.17 \\
0.15\end{array}$ & $\begin{array}{c}-0.04 \\
0.71\end{array}$ & $\begin{array}{l}0.07 \\
0.56\end{array}$ & $\begin{array}{l}0.15 \\
0.21\end{array}$ & $\begin{array}{l}0.16 \\
0.17\end{array}$ & $\begin{array}{c}0.38 \\
0.001\end{array}$ \\
\hline $\begin{array}{c}\text { IL-6 } \\
\left(\mathrm{pg} \mathrm{ml}^{-1}\right)\end{array}$ & $\begin{array}{l}294.38 \\
(516.6)\end{array}$ & $\begin{array}{c}0.71 \\
<0.001\end{array}$ & $\begin{array}{c}0.59 \\
<0.001\end{array}$ & & $\begin{array}{c}0.44 \\
<0.001\end{array}$ & $\begin{array}{c}0.31 \\
<0.01\end{array}$ & $\begin{array}{l}0.27 \\
0.02\end{array}$ & $\begin{array}{c}0.31 \\
<0.01\end{array}$ & $\begin{array}{l}0.18 \\
0.12\end{array}$ & $\begin{array}{l}0.29 \\
0.01\end{array}$ & $\begin{array}{c}0.43 \\
<0.001\end{array}$ \\
\hline $\begin{array}{l}\text { IL-1beta } \\
\left(\mathrm{pg} \mathrm{ml}^{-1}\right)\end{array}$ & $\begin{array}{c}95.48 \\
(37.62)\end{array}$ & $\begin{array}{l}0.25 \\
0.03\end{array}$ & $\begin{array}{l}0.19 \\
0.09\end{array}$ & $\begin{array}{c}0.44 \\
<0.001\end{array}$ & & $\begin{array}{c}0.44 \\
<0.001\end{array}$ & $\begin{array}{l}0.11 \\
0.35\end{array}$ & $\begin{array}{c}0.50 \\
<0.001\end{array}$ & $\begin{array}{l}0.25 \\
0.03\end{array}$ & $\begin{array}{l}0.01 \\
0.91\end{array}$ & $\begin{array}{c}0.70 \\
<0.001\end{array}$ \\
\hline $\begin{array}{c}\text { CCL2 } \\
\left(\mathrm{pg} \mathrm{ml}^{-1}\right)\end{array}$ & $\begin{array}{c}746.58 \\
(518.12)\end{array}$ & $\begin{array}{l}0.13 \\
0.26\end{array}$ & $\begin{array}{l}0.17 \\
0.15\end{array}$ & $\begin{array}{c}0.31 \\
<0.01\end{array}$ & $\begin{array}{c}0.44 \\
<0.001\end{array}$ & & $\begin{array}{l}0.21 \\
0.06\end{array}$ & $\begin{array}{c}0.43 \\
<0.001\end{array}$ & $\begin{array}{l}0.10 \\
0.37\end{array}$ & $\begin{array}{l}0.24 \\
0.03\end{array}$ & $\begin{array}{l}0.08 \\
0.47\end{array}$ \\
\hline $\begin{array}{c}\text { CCL3 } \\
\left(\mathrm{pg} \mathrm{ml}^{-1}\right)\end{array}$ & $\begin{array}{l}177.80 \\
(58.40)\end{array}$ & $\begin{array}{l}0.10 \\
0.40\end{array}$ & $\begin{array}{c}-0.04 \\
0.71\end{array}$ & $\begin{array}{l}0.27 \\
0.02\end{array}$ & $\begin{array}{l}0.11 \\
0.35\end{array}$ & $\begin{array}{l}0.21 \\
0.06\end{array}$ & & $\begin{array}{c}0.29 \\
<0.01\end{array}$ & $\begin{array}{l}0.04 \\
0.73\end{array}$ & $\begin{array}{l}0.06 \\
0.60\end{array}$ & $\begin{array}{c}-0.11 \\
0.36\end{array}$ \\
\hline $\begin{array}{c}\text { CCL4 } \\
\left(\mathrm{pg} \mathrm{ml}^{-1}\right)\end{array}$ & $\begin{array}{c}2886.28 \\
(1974.73)\end{array}$ & $\begin{array}{l}0.04 \\
0.73\end{array}$ & $\begin{array}{l}0.07 \\
0.56\end{array}$ & $\begin{array}{c}0.31 \\
<0.01\end{array}$ & $\begin{array}{c}0.50 \\
<0.001\end{array}$ & $\begin{array}{c}0.43 \\
<0.001\end{array}$ & $\begin{array}{c}0.29 \\
<0.01\end{array}$ & & $\begin{array}{c}-0.005 \\
0.96\end{array}$ & $\begin{array}{l}0.03 \\
0.80\end{array}$ & $\begin{array}{c}0.34 \\
<0.01\end{array}$ \\
\hline $\begin{array}{c}\text { CCL7 } \\
\left(\mathrm{pg} \mathrm{ml}^{-1}\right)\end{array}$ & $\begin{array}{c}80.81 \\
(13.72)\end{array}$ & $\begin{array}{l}0.03 \\
0.77\end{array}$ & $\begin{array}{l}0.15 \\
0.21\end{array}$ & $\begin{array}{l}0.18 \\
0.12\end{array}$ & $\begin{array}{l}0.25 \\
0.03\end{array}$ & $\begin{array}{l}0.10 \\
0.37\end{array}$ & $\begin{array}{l}0.04 \\
0.73\end{array}$ & $\begin{array}{c}-0.005 \\
0.96\end{array}$ & & $\begin{array}{l}0.15 \\
0.20\end{array}$ & $\begin{array}{c}0.40 \\
<0.001\end{array}$ \\
\hline $\begin{array}{l}\text { CXCL9 } \\
\left(\mathrm{pg} \mathrm{m}^{-1}\right)\end{array}$ & $\begin{array}{c}3161.89 \\
(2146.07)\end{array}$ & $\begin{array}{c}0.31 \\
<0.01\end{array}$ & $\begin{array}{l}0.16 \\
0.17\end{array}$ & $\begin{array}{l}0.29 \\
0.01\end{array}$ & $\begin{array}{l}0.01 \\
0.91\end{array}$ & $\begin{array}{l}0.24 \\
0.03\end{array}$ & $\begin{array}{l}0.06 \\
0.60\end{array}$ & $\begin{array}{l}0.03 \\
0.80\end{array}$ & $\begin{array}{l}0.15 \\
0.20\end{array}$ & & $\begin{array}{l}003 \\
0.77\end{array}$ \\
\hline $\begin{array}{c}\text { MIF } \\
\left(\mathrm{pg} \mathrm{ml}^{-1}\right)\end{array}$ & $\begin{array}{c}7240.52 \\
(5461.40)\end{array}$ & $\begin{array}{l}0.28 \\
0.01\end{array}$ & $\begin{array}{c}0.38 \\
0.001\end{array}$ & $\begin{array}{c}0.43 \\
<0.001\end{array}$ & $\begin{array}{c}0.70 \\
<0.001\end{array}$ & $\begin{array}{l}0.08 \\
0.47\end{array}$ & $\begin{array}{c}-0.11 \\
0.36\end{array}$ & $\begin{array}{c}0.34 \\
<0.01\end{array}$ & $\begin{array}{l}003 \\
0.77\end{array}$ & $\begin{array}{c}0.40 \\
<0.001\end{array}$ & \\
\hline
\end{tabular}

Abbreviations: $\mathrm{CCL}=$ chemokine (C-C motif) ligand; $\mathrm{CRP}=\mathrm{C}$-reactive protein; $\mathrm{CXCL}=$ chemokine (C-X-C motif) ligand; $\mathrm{IL}=$ interleukin; $\mathrm{MIF}=$ macrophage-migration-inhibitory factor; PTX3 $=$ pentraxin 3. ${ }^{*} r$ and $P$-values calculated using Spearman's rank correlation coefficient analysis.

Known to be a soluble recognition receptor, PTX3 binds to selected pathogens and has a non-redundant protective role against these pathogens as part of an innate immunological response. PTX3 also interacts with other biologically active molecules, such as fibroblast growth factor-2 (FGF2; Camozzi et al, 2006), to suppress FGF2-mediated cell-migration angiogenesis (Basile et al., 2013). In androgen-regulated breast cancer cells, PTX3 inhibits FGF8-driven cell proliferation (Leali et al, 2011). In contrast, PTX3 promotes VEGF-stimulated migration of pancreatic carcinoma cells, although exerting no influence on VEGF-dependent angiogenesis and cell migration and not interacting with VEGF (Basile et al, 2013).

Invasion of malignant cells was found to result in increased levels of inflammatory mediators, such as TNF-alpha, IL-1beta, and IL-6, that increase the ability of malignant cells to infiltrate, migrate, and metastasise, possibly as a result of the upregulation of chemokine-receptor expression elicited by these mediators (Mantovani et al, 2008). The results of this study indicate that direct PTX3 stimulation promotes pancreatic carcinoma cellmigration activity. This finding and that of the present study, specifically that high PTX3 level is significantly correlated with a more advanced stage of pancreatic cancer, indicates that PTX3 acts as a mediator of inflammation that has a tumour-promoting effect in pancreatic carcinoma cells. In a previous study, PTX3 expression was found to be higher in high-Gleason-grade prostate tumour tissue compared with contralateral prostate lobes, possibly in association with pro-inflammatory and repair-process activation (Ravenna et al, 2009). Similar results have been reported for 
human mammary-invasive carcinoma in association with hypoxiadriven HIF- $1 \alpha$ and NF- $\kappa$ B activation (Tafani et al, 2010). These findings, along with the knowledge that pro-inflammatory signals upregulate PTX3 expression in different mesenchymal and epithelial cell types (Garlanda et al, 2005), suggest that PTX3 has a role in tumour activation, invasion, and migration in some types of cancer. On the other hand, some results suggest that PTX3 expression is silenced in cancer cells at a relatively early stage of tumour progression in parallel with hypoxia- or inflammationdriven cytokine production by stromal components and inflammatory cell infiltrates. To clarify these contradictory findings and determine the true nature of the effect of PTX3 expression on cancer cells, further studies are required.

Previous studies of advanced pancreatic carcinoma patients have found median OS to be 8-12 months for patients who present with locally advanced unresectable disease but only 3-6 months for those who present with metastases or recurrent pancreatic carcinoma. Several studies of advanced pancreatic carcinoma patients who have undergone gemcitabine monotherapy reported that median OS after treatment ranged from 5.4 to 7.2 months (Burris et al, 1997; Berlin et al, 2002; Herrmann et al, 2007). In the present study, the median OS of patients with high PTX3 levels was remarkably brief, found to be only 117 days. Other well-known prognostic factors in pancreatic carcinoma patients are elevated serum level of CA19-9, a widely used prognostic marker and indicator of disease activity (Ueno et al, 2000; Berger et al, 2008; Tanaka et al, 2008; Morizane et al, 2011), and elevated CRP level, which is likely to be part of the systemic inflammatory response to tumour development. Activation of CRP has also been linked to cancer cachexia, characterised by malnutrition and an accelerated starvation state, and shorter OS (Ebrahimi et al, 2004). Despite the importance of these factors, the findings of this study indicate that elevated PTX3 level is associated with more advanced disease and poorer PS, and is therefore a more useful neo-factor in prognosis than CA19-9 and CRP in pancreatic carcinoma patients.

Pro-inflammatory mediators are frequently expressed in the tumour microenvironment after they have infiltrated leukocyte, stromal, and cancer cells (DeNardo et al, 2008; Mantovani et al, 2008). Several mediators, such as IL-1beta, enhance the production of PTX3 elicited by inflammatory signalling (Polentarutti et al, 1998), whereas others, such as IL-6, CCL2, and interferon-gamma, have negligible effects on PTX3 expression (Alles et al, 1994; Polentarutti et al, 1998). Previous studies have found PTX3 levels to be correlated with CRP, IL-6, and elevated levels of MIF, which are known to control autonomous properties of tumour cells, such as proliferation, apoptosis, DNA-damage response, senescence, and invasion (Dessein et al, 2010), in the tumour and serum of pancreatic cancer patients (Winner et al, 2007).

In consideration with these findings, the present study aimed to clarify the profile of these mediators in pancreatic carcinoma patients and the correlations among them. Although this study yielded significant findings, it was limited by several phenomena, for instance the insufficient insolubility of the mechanism between each mediator and the inability to examine the intricate interrelations among the inflammatory mediators of cancer patients, each of which has multiple roles in various tumorigenic behaviours.

In conclusion, the results of this study provide strong evidence that elevated levels of pentraxin family members, especially PTX3, are associated with poor prognosis in pancreatic carcinoma patients. Expression of PTX3 appears to be a promising biomarker for pancreatic carcinoma prognosis. However, the mechanism of tumour inflammation and exact nature of the role of PTX3 expression remains unclear, calling for investigation of the mechanisms underlying PTX3 activity in carcinoma cells and the tumour environment.

\section{ACKNOWLEDGEMENTS}

We express our appreciation to Rubi Mukoyama, Keiko Kondo, and Yuki Kitamura for collecting the clinical data. This work was supported in part by the National Cancer Center Research and Development Fund (23-A-14 and 23-A-22).

\section{CONFLICT OF INTEREST}

The authors declare no conflict of interest.

\section{REFERENCES}

Alles VV, Bottazzi B, Peri G, Golay J, Introna M, Mantovani A (1994) Inducible expression of PTX3, a new member of the pentraxin family, in human mononuclear phagocytes. Blood 84(10): 3483-3493.

Basile A, Moschetta M, Ditonno P, Ria R, Marech I, De Luisi A, Berardi S, Frassanito MA, Angelucci E, Derudas D, Specchia G, Curci P, Pavone V, Rossini B, Ribatti D, Bottazzi B, Mantovani A, Presta M, Dammacco F, Vacca A (2013) Pentraxin 3 (PTX3) inhibits plasma cell/stromal cell cross-talk in the bone marrow of multiple myeloma patients. J Pathol 229(1): 87-98.

Berger AC, Garcia M, Hoffman JP, Regine WF, Abrams RA, Safran H, Konski A, Benson AB, MacDonald J, Willett CG (2008) Postresection CA 19-9 predicts overall survival in patients with pancreatic cancer treated with adjuvant chemoradiation: a prospective validation by RTOG 9704 . J Clin Oncol 26(36): 5918-5922.

Berlin JD, Catalano P, Thomas JP, Kugler JW, Haller DG, Benson AB (2002) Phase III study of gemcitabine in combination with fluorouracil versus gemcitabine alone in patients with advanced pancreatic carcinoma: Eastern Cooperative Oncology Group Trial E2297. J Clin Oncol 20(15): 3270-3275.

Burris HA, Moore MJ, Andersen J, Green MR, Rothenberg ML, Modiano MR, Cripps MC, Portenoy RK, Storniolo AM, Tarassoff P, Nelson R, Dorr FA, Stephens CD, Von Hoff DD (1997) Improvements in survival and clinical benefit with gemcitabine as first-line therapy for patients with advanced pancreas cancer: a randomized trial. J Clin Oncol 15(6): 2403-2413.

Camozzi M, Rusnati M, Bugatti A, Bottazzi B, Mantovani A, Bastone A, Inforzato A, Vincenti S, Bracci L, Mastroianni D, Presta M (2006) Identification of an antiangiogenic FGF2-binding site in the $\mathrm{N}$ terminus of the soluble pattern recognition receptor PTX3. J Biol Chem 281(32): 22605-22613.

DeNardo DG, Johansson M, Coussens LM (2008) Immune cells as mediators of solid tumor metastasis. Cancer Metastasis Rev 27(1): 11-18.

Dessein AF, Stechly L, Jonckheere N, Dumont P, Monté D, Leteurtre E, Truant S, Pruvot FR, Figeac M, Hebbar M, Lecellier CH, Lesuffleur T, Dessein R, Grard G, Dejonghe MJ, de Launoit Y, Furuichi Y, Prévost G, Porchet N, Gespach C, Huet G (2010) Autocrine induction of invasive and metastatic phenotypes by the MIF-CXCR4 axis in drug-resistant human colon cancer cells. Cancer Res 70(11): 4644-4654.

Diamandis EP, Goodglick L, Planque C, Thornquist MD (2011) Pentraxin-3 is a novel biomarker of lung carcinoma. Clin Cancer Res 17(8): 2395-2399.

Doni A, Mantovani G, Porta C, Tuckermann J, Reichardt HM, Kleiman A, Sironi M, Rubino L, Pasqualini F, Nebuloni M, Signorini S, Peri G, Sica A, Beck-Peccoz P, Bottazzi B, Mantovani A (2008) Cell-specific regulation of PTX3 by glucocorticoid hormones in hematopoietic and nonhematopoietic cells. J Biol Chem 283(44): 29983-29992.

Doni A, Peri G, Chieppa M, Allavena P, Pasqualini F, Vago L, Romani L, Garlanda C, Mantovani A (2003) Production of the soluble pattern recognition receptor PTX3 by myeloid, but not plasmacytoid, dendritic cells. Eur J Immunol 33(10): 2886-2893.

Ebrahimi B, Tucker SL, Li D, Abbruzzese JL, Kurzrock R (2004) Cytokines in pancreatic carcinoma: correlation with phenotypic characteristics and prognosis. Cancer 101(12): 2727-2736.

Garlanda C, Bottazzi B, Bastone A, Mantovani A (2005) Pentraxins at the crossroads between innate immunity, inflammation, matrix deposition, and female fertility. Annu Rev Immunol 23: 337-366. 
Germano G, Frapolli R, Simone M, Tavecchio M, Erba E, Pesce S, Pasqualini F, Grosso F, Sanfilippo R, Casali PG, Gronchi A, Virdis E, Tarantino E, Pilotti S, Greco A, Nebuloni M, Galmarini CM, Tercero JC, Mantovani A, D'Incalci M, Allavena P (2010) Antitumor and anti-inflammatory effects of trabectedin on human myxoid liposarcoma cells. Cancer Res 70(6): 2235-2244.

Han B, Mura M, Andrade CF, Okutani D, Lodyga M, dos Santos CC, Keshavjee S, Matthay M, Liu M (2005) TNFalpha-induced long pentraxin PTX3 expression in human lung epithelial cells via JNK. J Immunol 175(12): 8303-8311.

Herrmann R, Bodoky G, Ruhstaller T, Glimelius B, Bajetta E, Schüller J, Saletti P, Bauer J, Figer A, Pestalozzi B, Köhne CH, Mingrone W, Stemmer SM, Tàmas K, Kornek GV, Koeberle D, Cina S, Bernhard J, Dietrich D, Scheithauer W (2007) Gemcitabine plus capecitabine compared with gemcitabine alone in advanced pancreatic cancer: a randomized, multicenter, phase III trial of the Swiss Group for Clinical Cancer Research and the Central European Cooperative Oncology Group. J Clin Oncol 25(16): 2212-2217.

Jaillon S, Peri G, Delneste Y, Frémaux I, Doni A, Moalli F, Garlanda C, Romani L, Gascan H, Bellocchio S, Bozza S, Cassatella MA, Jeannin P, Mantovani A (2007) The humoral pattern recognition receptor PTX3 is stored in neutrophil granules and localizes in extracellular traps. J Exp Med 204(4): 793-804.

Jemal A, Bray F, Center MM, Ferlay J, Ward E, Forman D (2011) Global cancer statistics. CA Cancer J Clin 61: 69-90.

Klouche M, Peri G, Knabbe C, Eckstein HH, Schmid FX, Schmitz G, Mantovani A (2004) Modified atherogenic lipoproteins induce expression of pentraxin- 3 by human vascular smooth muscle cells. Atherosclerosis 175(2): 221-228.

Kondo S, Iwata S, Yamada T, Inoue Y, Ichihara H, Kichikawa Y, Katayose T, Souta-Kuribara A, Yamazaki H, Hosono O, Kawasaki H, Tanaka H, Hayashi Y, Sakamoto M, Kamiya K, Dang NH, Morimoto C (2012a) Impact of the integrin signaling adaptor protein NEDD9 on prognosis and metastatic behavior of human lung cancer. Clin Cancer Res 18(22): 6326-6338.

Kondo S, Ueno H, Hashimoto J, Morizane C, Koizumi F, Okusaka T, Tamura K (2012b) Circulating endothelial cells and other angiogenesis factors in pancreatic carcinoma patients receiving gemcitabine chemotherapy. BMC Cancer 12(1): 268.

Leali D, Alessi P, Coltrini D, Ronca R, Corsini M, Nardo G, Indraccolo S, Presta M (2011) Long pentraxin-3 inhibits FGF8b-dependent angiogenesis and growth of steroid hormone-regulated tumours. Mol Cancer Ther 10(9): 1600-1610.

Mantovani A, Allavena P, Sica A, Balkwill F (2008) Cancer-related inflammation. Nature 454(7203): 436-444.

Morizane C, Okusaka T, Morita S, Tanaka K, Ueno H, Kondo S, Ikeda M, Nakachi K, Mitsunaga S (2011) Construction and validation of a prognostic index for patients with metastatic pancreatic adenocarcinoma. Pancreas 40(3): 415-421.

Norata GD, Marchesi P, Pirillo A, Uboldi P, Chiesa G, Maina V, Garlanda C, Mantovani A, Catapano AL (2008) Long pentraxin 3, a key component of innate immunity, is modulated by high-density lipoproteins in endothelial cells. Arterioscler Thromb Vasc Biol 28(5): 925-931.

Polentarutti N, Picardi G, Basile A, Cenzuales S, Rivolta A, Matteucci C, Peri G, Mantovani A, Introna M (1998) Interferon-gamma inhibits expression of the long pentraxin PTX3 in human monocytes. Eur J Immunol 28(2): 496-501.

Ravenna L, Sale P, Di Vito M, Russo A, Salvatori L, Tafani M, Mari E, Sentinelli S, Petrangeli E, Gallucci M, Di Silverio F, Russo MA (2009) Up-regulation of the inflammatory-reparative phenotype in human prostate carcinoma. Prostate 69(11): 1245-1255.

Sardana G, Jung K, Stephan C, Diamandis EP (2008) Proteomic analysis of conditioned media from the PC3, LNCaP, and 22Rv1 prostate cancer cell lines: discovery and validation of candidate prostate cancer biomarkers. J Proteome Res 7(8): 3329-3338.

Tafani M, Russo A, Di Vito M, Sale P, Pellegrini L, Schito L, Gentileschi S, Bracaglia R, Marandino F, Garaci E, Russo MA (2010) Up-regulation of pro-inflammatory genes as adaptation to hypoxia in MCF-7 cells and in human mammary invasive carcinoma microenvironment. Cancer Sci 101(4): 1014-1023.

Tanaka T, Ikeda M, Okusaka T, Ueno H, Morizane C, Hagihara A, Iwasa S, Kojima Y (2008) Prognostic factors in japanese patients with advanced pancreatic cancer treated with single-agent gemcitabine as first-line therapy. Jpn J Clin Oncol 38(11): 755-761.

Ueno H, Okada S, Okusaka T, Ikeda M (2000) Prognostic factors in patients with metastatic pancreatic adenocarcinoma receiving systemic chemotherapy. Oncology 59(4): 296-301.

Vincent A, Herman J, Schulick R, Hruban RH, Goggins M (2011) Pancreatic cancer. Lancet 378(9791): 607-620.

Willeke F, Assad A, Findeisen P, Schromm E, Grobholz R, von Gerstenbergk B, Mantovani A, Peri S, Friess HH, Post S, von Knebel Doeberitz M, Schwarzbach MH (2006) Overexpression of a member of the pentraxin family (PTX3) in human soft tissue liposarcoma. Eur J Cancer 42(15): 2639-2646.

Winner M, Koong AC, Rendon BE, Zundel W, Mitchell RA (2007) Amplification of tumor hypoxic responses by macrophage migration inhibitory factor-dependent hypoxia-inducible factor stabilization. Cancer Res 67(1): 186-193.

This work is published under the standard license to publish agreement. After 12 months the work will become freely available and the license terms will switch to a Creative Commons AttributionNonCommercial-Share Alike 3.0 Unported License. 